ISSN e- 2594-1100

en-claves del pensamiento / núm. 30 / julio-diciembre / 2021 / e470

https://doi.org/10.46530/ecdp.v0i30.470 ENTREVISTAS Y

REFLEXIONES

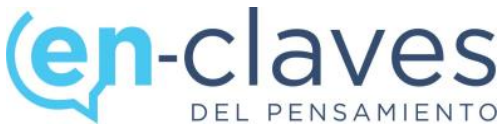

DEL PENSAMIENTO

\title{
TÁCITO Y LA DESTRUCCIÓN DE CREMONA. EL PODER DE LA CODICIA
}

Tacitus and the Destruction of Cremona. The Power of Greed

Antonio Hermosa Andújar, Universidad de Sevilla, España

Correo electrónico: hermosa@us.es

Recibido: $10 / 12 / 2020$

Aceptado: $15 / 03 / 2021$

Publicado: 01/07/2021

Resumen. En este texto Antonio Hermosa Andújar, catedrático de Filosofía Antigua, bellamente reflexiona sobre la destrucción de Cremona. Desde la perspectiva de Tácito da cuenta de la violencia de la guerra, la compleja situación psíquica de los combatientes, las pasiones y en especial la codicia.

Palabras clave: destrucción de Cremona, filosofía antigua, codicia.

Abstract. In this text Antonio Hermosa Andújar, professor of Ancient Philosophy, beautifully reflects on the destruction of Cremona. From the perspective of Tacitus, he gives an account of the violence of war, the complex psychic situation of the combatants, the passions and especially greed.

Keywords: Destruction of Cremona, Ancient Philosophy, greed.

Hermosa Andújar, A. (2021). Tácito y la destrucción de Cremona. El poder de la codicia. EN-CLAVES del pensamiento, O(30), e470. doi: https://doi.org/10.46530/ecdp.v0i30.470 
Sic est: acerba fata Romanos agunt

Scelusque fraternae necis.

Horacio

\section{A modo de prólogo: El incendio del Capitolio}

No era la primera vez que el Capitolio ardía. También antaño, como ahora, fueron las llamas de la guerra civil las que le prendieron fuego; pero entonces fue fechoría privada, en tanto hoy crepita el odio público. La construcción del templo había sido la promesa que los reyes romanos dejaron en prenda al futuro por la insigne grandeza de la joven ciudad y, después, el testigo con el que la libertad se conjuró consigo misma a impedir, bajo forma de res publica, que los reyes suplantaran en el orden natural al senado y al pueblo romanos. Las cenizas del Capitolio dejaban entrever los sueños de grandeza en su nueva versión, pero enterraban como ilusión los restos de la libertad, y, con ella, la panoplia de ideales con los que se llegó a creer eterna: era la pietas hacia los dioses, la religio de los padres, la fides hacia Roma, la unidad del pasado, el orgullo de su historia, la devoción a las leyes, en suma, el conjunto de verdades que había cimentado la república, lo que veían consumirse en un fuego que ahora parecía tan eterno como su antiguo sueño, aunque mucho más real.

Y más todavía: el resplandor de esas llamas, contemplado en la lejanía del tiempo por los galos izados en rebeldía contra el imperio, quemaba algo más; signo de un cambio de designio de Júpiter en su relación con Roma al consentir la destrucción de su propio hogar otrora preservado por él mismo, las llamas no sólo incineran el pasado republicano y sus ideales, sino que en la mente gala incendian también su futuro imperial; arde, pues, a un tiempo la gloria republicana y el destino de la Roma de los césares. Cambiando de pueblo al abandonar su hogar devastado, Júpiter adopta al pueblo sublevado para recuperar su libertad, garantiza su propósito de destruir al que lo oprime y, en fin, sella a fuego el pasado y el futuro de la Urbe. ${ }^{1}$

\footnotetext{
${ }^{1}$ Historias, IV, tr. José Luis Moralejo (Akal: Madrid, 1990), 52, 2.
} 
Tácito deploraba dicho incendio como "el más lamentable y vergonzoso atentado que padeció la república del pueblo romano [rei publicae populi Romani] desde la fundación de la Urbe", obra tanto más dolorosa en cuanto autoinfligida sin amenazas externas y con el favor aparente de los dioses. ${ }^{2} \mathrm{Y}$ es que cuanto las guerras continuas contra los enemigos externos no habían conseguido brotó casi graciosamente de las guerras civiles, cuando el decrépito cuerpo del poder romano fue descuartizado por las luchas en torno a la sucesión del imperio y la paz y la concordia debieron su ser fundamentalmente a la violencia. Roma se venció a sí misma, una Roma que cambiaba de naturaleza y de dioses en función del botín político obtenido con la victoria; sepultada la libertad, la grandeza tenía el prestigio que le otorgaban las armas, y devino tan enorme que pareció absoluto. Empero, la gloria militar excavaba en el pecho de sus ciudadanos madrigueras que la codicia, y el conjunto de criaturas de la noche que ella saca a la luz, transformaron en genuinas ciudadelas del egoísmo que acabaron minando el poder de unas armas sin apenas rival al enfrentarse a otras como ellas. ${ }^{3}$ Una densa muestra de cuanto sucedió antes de llegar ahí se advierte al analizar la destrucción de Cremona, y un indicio de por dónde seguirían su triunfal recorrido en el ánimo la codicia y su séquito pasional se imprime en las acciones del pueblo espectador con que, a modo de epílogo, concluiremos el presente trabajo.

\section{La destrucción de Cremona}

\section{Cuando decidir es un enigma}

La guerra civil prosigue su curso victorioso a lo largo y ancho del vasto escenario de la política romana. Ya dos emperadores, Galba y Otón, han perecido a manos de la espada, y el tercero en la sucesión — desde que el ejército reemplazara al senado asumiendo por la fuerza su función en el nombramiento del candidato-, Vitelio, intuye esa suerte para

\footnotetext{
2 "Si es que nuestra conducta lo hacía posible". Ibid., III, 72, 1.

${ }^{3}$ Por no hablar aquí del instinto de emulación que segrega en quienes a veces la recrean y con frecuencia la padecen, instinto que los lleva a robarla de donde está y recuperarla para sí.
} 
él como resultado previsible de su actual guerra contra Vespasiano por mantenerse en el trono. Esos simples hechos, junto al amplio cortejo de perversiones y peligros que son en sí mismos para la existencia de Roma y la vida de sus habitantes, dan idea de la vorágine que define el estado actual de la ciudad y la incertidumbre que acecha la suerte de los ciudadanos. También relucen anécdotas que apuntan a idéntico blanco de manera más modesta, como la del hijo que encuentra al padre alistado en el bando rival, y al que sólo descubre como tal tras darle muerte en su duelo personal; entonces el arrepentimiento llega tarde para calmar el dolor lancinante que siente, aunque quizá no el perdón de los manes paternos al que aspira. La solidaridad de quienes le rodean al descubrir la situación es un canto a la humanidad que aún caldea sus corazones pese al frío polar del ambiente.

Mas, de hecho, la normalidad no ha cesado, porque ni el dolor por "la crueldad de la guerra", ni la compasión despertada impiden, dice Tácito, que se degüelle y despoje con menor afán a parientes, allegados y hermanos. Y sentencia: "hablan de que se ha cometido un crimen, y lo cometen". ${ }^{4}$ Como decir que quienes claman contra el crimen claman en realidad contra un crimen que les afecta más o menos directamente, pero si en los demás actúan como criminales, quizá es que en aquél declamen como plañideras. Así pues, tanto en los grandes acontecimientos como en los sucesos menudos el alma de Roma se halla a la intemperie, y lo que ahí se advierte al contemplarla infunde consternación y pavor.

En este punto tal vez convenga formular una serie de interrogantes mediante los cuales intentar elucidar la compleja situación psicológica y moral sobrevenida y clarificar la reacción en la misma de parte de quienes la protagonizan. Combatir día y noche ha llevado al combatiente a la extenuación; en ese punto, en el que una fatiga virtuosa pulveriza los músculos del cuerpo y, con ellos, los del ánimo, donde la vida finge entreverar sus aguas con las de la muerte, ¿qué divinidad hay más fuerte que la debilidad extrema en grado de cicatrizar sus heridas devolviendo de golpe el vigor al cuerpo y la juventud al espíritu? ¿Cuál es la magia capaz de ilusionar repentinamente al nihilismo fisiológico, llenar de color unos ojos moribundos y de calor un brazo que ya ha desertado la espada que lo defiende? Y, ¿quién seduce al ánimo con un turbulento despertar así?

\footnotetext{
${ }^{4}$ Historias, III, 25, 3 .
} 
En el ciclo infinito de hostilidades en el que se ven envueltas las tropas del emperador real y del emperador in pectore, Cremona les fija una cita. Ante su vista, las tropas del segundo, fatigadas en extremo por el viaje y las luchas, reciben un impacto demoledor, una tenaza formada por la historia y el contexto que levanta una firme muralla contra sus propósitos de conquista. La historia aporta la fuerza de una ciudad pujante y bien defendida, erigida junto al Po como barrera contra las previsibles incursiones galas, pero a la que su situación y el comercio han engrandecido y fortalecido; las circunstancias añaden dos factores de peso a su potencia, a saber, las fortificaciones recientemente construidas por las tropas germanas en su enfrentamiento contra Otón y el hecho de estar celebrándose un mercado regional que ha congregado a numerosas gentes de otras localidades dispuestas a sumarse a la defensa de la ciudad.

El pasmo que paraliza al ejército de Vespasiano, en el que Tácito compendia el impacto ocular del espectáculo antedicho sobre el ánimo de sus miembros, no sólo intensifica de repente la fatiga de sus integrantes, sino que al minar con dudas la capacidad de reacción de los jefes la decisión a tomar aquí y ahora terminará por tornarse un enigma. El primer abismo del qué hacer, si atacar ya o postergarlo, configura un duelo de la naturaleza humana consigo misma sirviéndose de dos elementos radicalizados. La fatiga que roe los miembros de los soldados se opone con vehemencia a entrar en combate ya, máxime cuando no es posible contar con refuerzos. La psicología, en cambio, arguye que es un alto precio derrochar esa energía ahora fatigada, es decir, aceptar el descanso sin su premio. El segundo abismo del qué hacer nace de una posible respuesta al primero; esto es, la construcción de un campamento fortificado, pero la táctica halla respuesta dentro de sí misma: el enemigo también se defiende atacando, y los muchos brazos ocupados en dicha tarea roban fuerza a la posibilidad de defenderse con éxito llegado el caso.

Hay una tercera duda, la más básica y elemental, que transforma decidir en un enigma, dado que afecta no a la orientación de la decisión, sino a su propia existencia: si es posible tomarla o no. Suena como poco a paradoja que los jefes de un ejército, forzados por la naturaleza de su rango a decidir, se planteen si pueden hacerlo o no, pero Tácito expone de un solo trazo y con rotundidad el enigma y su causa: a tales jefes, "más 
que todo eso los asustaba su propia tropa, la cual — añade — más soportaba el peligro que la demora". La crisis de poder que ha afectado a su ejercicio a lo largo y ancho del imperio ha alcanzado según se ve también al ejército, el instrumento con el que una sociedad, ya sea para defenderse o para atacar, ha de tener siempre listo y a punto para su intervención, un rasgo decisivo para su seguridad. Que los soldados se otorguen licencia para obedecer o no a sus jefes; que la disciplina llegue a saltar por los aires por mor del capricho de quienes deben ser sus esclavos, pone en jaque la consistencia del dominio romano en el exterior tanto como su unidad interna, a la par que demuestra cuán próximo se halla el mayor centro político del mundo en esa época de la anarquía.

Los jefes no saben qué hacer porque no mandan ante su tropa. La razón de la indisciplina - la duda es ya manifestación tajante de la misma - latente en el ejército, y de que la sorpresa gobierne ocasionalmente sobre las propias armas yace en un precepto en apariencia aséptico de la naturaleza humana, pero que en determinados contextos, como el actual, se revela de una fuerza demoledora: "y es que se estima poco lo seguro, y la temeridad engendra esperanza". Ni la obediencia debida, ni los valores o ideas que la sustentan, ni el castigo que conlleva infringir el mando, ni el peligro que puede generar una conducta semejante, ni el precedente con el que amenaza perpetuarse: nada impide que, en determinadas circunstancias, algunos individuos aspiren a llegar a ser los bastantes como para desafiar al destino en una sociedad y de jugar con la muerte en un doble escenario, el que concierne al grupo en cuanto actores de una acción rebelde y el que afecta al conjunto de la sociedad a la que traicionan.

Ahora bien, ¿cualquier esperanza incita a la temeridad a declarar su comunidad estado de naturaleza? ¿Toda esperanza vale lo que otra o hay alguna esperanza concreta, o algunas, algún de qué que dé forma a la esperanza e inste a quien la tiene a revolver Roma con Santiago, a revolucionar su propia sociedad, con tal de satisfacer sus instintos, proyectos o necesidades, con un grado mayor o menor de urgencia? Las preguntas espeluznantes en sí mismas - ni siquiera anuncian la tenebrosa respuesta: "Todas las matanzas, heridas y sangrías se compensaban con la avidez de botín". 5 Hemos llegado al reino de la codicia, que vuelve pequeños todos los demás, y que cuando impera en

\footnotetext{
${ }^{5}$ Ibid., III, 26, 3 (cursivas nuestras).
} 
semejante forma sobre los dominios del corazón humano no hay límite, regla, modelo, tiempo o sociedad que valga; es el yo, el yo absoluto, la razón para el temor perenne de cualquier grupo constituido, el conjunto de yos en el que se ha disuelto el grupo levantisco, la máxima expresión de poder individual e interpersonal, organizado pero desunido, concebible sobre la tierra. Es, en suma, el botín con el que la codicia nos pone a soñar, el punto de fuga donde todas las interrogantes iniciales se concitan, lo que invierte el orden natural en nuestra persona y devuelve toda la energía al cuerpo y al alma hundidos por la fatiga y sus impotencias.

\section{Codicia y guerra}

¿Por qué derroteros conduce la codicia a sus presas humanas? ¿Qué aporta la guerra a las acciones propiciadas por ella? Ante todo, conviene observar que, a pesar de su ferocidad, la codicia sabe que no es la única pasión que subleva al corazón y que no siempre es dominante, e incluso que, en medio de la nada civilizatoria, como puede llegar a ser la guerra, la razón dé las órdenes más ajustadas a su interés; de ahí que, en determinadas circunstancias, con humilde prudencia, dé un paso atrás y ceda a sus subordinados el dominio de la escena. Así, destruir la empalizada y asaltar las murallas quizá formen parte en cierto momento de dichas circunstancias, y entonces el arte militar echará mano de su sabiduría a fin no sólo de diferenciar "a esforzados y cobardes", sino de, en tal situación, que "se inflamaran al rivalizar en pundonor"; o bien acarreará, más allá de la organización de la tropa, materiales extraídos de la psicología con los que proceder a derribar las altas torres de piedra a las que tan alta cuota de su seguridad fían los defensores. ${ }^{6}$

Ahora bien, la codicia permanece al acecho de los acontecimientos pronta a intervenir y mutar a su favor las señales desfavorables; y si esperamos un poco, al resultado del primer choque de Roma contra Roma, de la tortuga formada por los asaltantes contra el modo de desbaratarla por parte de los sitiados, advertiremos su

\footnotetext{
${ }^{6}$ Ibid., III, 27, 1 y III, 30, 1.
} 
irrupción inmediata en cuanto los primeros cedan ante el empuje de los segundos, pronta a quebrar la suerte adversa de los acontecimientos: en medio de "una formación de tortuga desorganizada y vacilante" oiremos su rugido en el pecho de los indecisos cuando los "jefes" señalen "Cremona a la tropa cansada y que rechazaba las arengas como inútiles"; justo en el instante en que Cremona toma la forma del botín una oleada de furia rejuvenece los miembros fatigados y les imprime un punto hacia el que avanzar sin detenerse, como si murallas y defensores se hubieran vuelto de aire. Sólo la codicia posee ese poder colectivo repentino y milagroso sobre sus sujetos; ella rehace, como si nada, la tortuga deshecha, reintegra la sangre a los cuerpos de los soldados y restaña sus heridas como si no se hubieran producido, y perpetúa su magia transformándolos en una máquina de piezas perfectamente encajadas que nada logrará refrenar antes de obtener su objetivo inmediato: "minar el recinto y golpear las puertas... y agarrar con las manos las armas y los brazos del enemigo". Tácito parece en este punto recordar la guerra de Corcira narrada por Tucídides al concluir lo que sigue con la narración del festín con el que la muerte celebró el fin de la jornada. ${ }^{7}$

Asimismo, cuando acto seguido las tropas invasoras, traspasada ya la muralla, se topan con un ejército rival extremadamente leal al actual emperador, al que se agregan además los muchos visitantes de paso por la ciudad con ocasión del próximo mercado, es decir, cuando la seguridad de la fuerza, de la legalidad y del interés se refuerza con la del número aleatoriamente incrementado, que podría oponer al avance de los sitiadores un obstáculo mayor que los físicos recién dejados atrás, es la codicia quien les cambia el sentido del espectáculo haciéndoles ver en esa multitud "un acicate" para incrementar "su botín", y quien urde planes con los que juega a fragmentar los intereses de los ciudadanos y les tienta a cambiar de bando. Sabiéndose patria común de los humanos, con independencia de la coyuntura que actualmente les enfrenta mediante la guerra, inspira a Antonio, el jefe del ejército de Vespasiano, la táctica a seguir: "ordena que cojan teas y peguen fuego a los edificios más hermosos de las afueras de la ciudad, por si los cremoneses, a la vista del daño sufrido por sus bienes, se avenían a mudar sus lealtades”.

\footnotetext{
7 "Ruedan ilesos junto con heridos, los medio muertos con los que expiraban, pereciendo de diversos modos y con todas las imágenes de la muerte". Ibid., III, 28 (cursivas nuestras).
} 
Tácito no nos relata cuál de los dos gladiadores combatía con mayor vigor en el pecho de los cremoneses, si sus intereses materiales, que les desvinculaban del cuerpo colectivo conformado por la energía espiritual que vinculaba su lealtad a una persona y se expresaba en la obediencia a sus órdenes y en la defensa de sus dominios, o esa misma energía. Ni siquiera hay tiempo para probar la genuina naturaleza de la misma una vez liberada del temor a la desobediencia: y es que, de repente, las tropas favorables a Vitelio perciben el desplome de su ánimo ante el cariz que van tomando los hechos. En este punto, el foco se traslada de los ciudadanos a la tropa y, al concentrarse sobre ésta, muestra las enormes fisuras ideológicas o de intereses que mueven a jefes y soldados, y cómo la guerra altera valores consolidados transustanciándolos en prejuicios, reconfigura el mapa normativo en favor del amor a la vida y cómo esa pasión, que unos y otros tienen en común, les distancia entre sí en su modo de defenderla, sobreponiéndose además al honor o a cualquier otra divinidad, incluida la del amor al emperador o al imperio, o la de su lealtad a Roma, ante la cual en otros tiempos se postrara.

En el momento de la rendición de los defensores de la ciudad ante sus asaltantes otras pasiones, que esperaban su turno velando armas, cobran protagonismo con el cambio de situación. El amor a la vida, o el deseo de sobrevivir, si se prefiere, llama en su auxilio a la esperanza, que aconseja a los jefes no tensar la cuerda del perdón, esto es, renunciar a la lucha, dado que la ira del vencedor suele tener poca paciencia y prefiere una muerte ilustre a otra vulgar; los soldados lo tienen más fácil, por cuanto desde el refugio de su anonimato siempre resultará más fácil escabullirse en los meandros de las sombras y esquivar los golpes del destino. Tanto, sentencia Tácito, que luego de "haber abandonado la guerra" "ni siquiera pedían la paz". ${ }^{8}$ Los jefes, en cambio, sabían que era insuficiente vivir al amparo de la noche, ya que el perdón requiere la visibilidad del arrepentimiento, aun si es falso, y ésta se derrama en acciones, como la de borrar las imágenes de la mancha anterior, es decir, el nombre y el recuerdo de Vitelio, procediendo pues a la destrucción de sus efigies.

Es también la hora de la humillación, del abatimiento, de la compasión e incluso de la venganza, preparada con mimo por el poderoso mientras andaba entre grilletes, $\mathrm{y}$

\footnotetext{
${ }^{8}$ Ibid., III, 31, 1-2.
} 
que irrumpe en la soberbia del ritual - la toga pretexta y los lictores que acompañan a Cécina - con el que éste reaparece en la escena pública; e incluso, y para su sorpresa, es la hora, en el mismo bando vencedor, de la ira contra esa soberbia a destiempo que interrumpía la cadena de emociones que iba desde la humillación de los vencidos a la congoja de los vencedores ante la misma, el instante mágico e inesperado en el que éstos sienten como de los suyos a los primeros. Todo había iniciado cuando los jefes liberan a Cécina $y$, en un alarde de indignidad que es como apretar sobre sí misma a la humillación, le piden con lágrimas de suplicante, cual si de una divinidad se tratara, que interceda por ellos ante los vencedores, a lo que sigue la altanera negativa de éste. Es entonces cuando tiene lugar la procesión de, en apariencia, cadáveres vivientes, pues a las “enseñas y águilas" de los vencedores sigue "un cortejo entristecido de hombres sin armas con la mirada en la tierra" que recuerda al de los romanos ante los samnitas en las Horcas Caudinas, de no ser porque el abatimiento de éstos se debía en primera instancia a su obligación de vivir para que Roma no pereciera; en tanto, el de aquéllos es simplemente el precio a pagar por sobrevivir a cualquier precio, una transacción barata desde el momento en que tras la misma quedan vivos.

Lo que, sin embargo, hace cambiar la actitud de los vencedores respecto de los vencidos es la natural aceptación por parte de éstos de la humillación, la ausencia de todo rastro de altivez en su compostura frente a los agravios recibidos, que traslada repentinamente a la memoria de los primeros la moderación con la que los humillados de ahora se habían comportado frente a los perdedores de antes tras su victoria. Surgía así ese sentimiento de compasión al que es fácil seguir el rastro desde los ojos al corazón de los espectadores, esa suerte de tentación unitaria en cuanto romanos de unos respecto de otros que la llegada fatua de Cécina interrumpe con sus ínfulas de grandeza. ${ }^{9}$ En medio de atribulaciones tan sentidas, de esa rara síntesis alcanzada entre pérdida de autoestima y serenidad, de un lado, y, del otro, de orgullo y compasión, y de la mezcla aún más asombrosa entre las pasiones de las partes, la codicia, se diría, se ha vuelto ermitaña y renunciando quizá a sus poderes haya abandonado la sociedad llevándose con ella hasta

\footnotetext{
${ }^{9}$ Y que le podía haber salido cara de no haber intervenido Antonio para aplacar los ánimos y enviar a Cécina junto a Vespasiano. Ibid., III, 31, 3-4.
} 
su propio recuerdo. ¡Vanas esperanzas quien las forjara ante criatura tan caníbal y depredadora!

Ante la plebe de Cremona la codicia apresó la ocasión de hacer nuevamente ostentación de poder. Otra intervención de Antonio ante su tropa evitó que fuera diezmada en la matanza que parecía haberse iniciado. Los soldados acatan la voz de su amo, saldada la crisis de autoridad que había transformado decidir qué hacer, cuáles órdenes impartir, en un enigma. Su discurso enhebra el valor de la clemencia hacia los vencidos en la lista de sujetos que gobiernan la escena de la guerra en ausencia de la codicia, y se contrapesa con palabras laudatorias hacia los suyos. El silencio es la única referencia a Cremona. Y la codicia ve allí la señal esperada para dar pasto a la "ingénita avidez del ejército": concita las fuerzas de su propia psicología y la memoria y ya todo es botín.

Digamos antes de nada que la codicia no necesita de otra justificación que ella misma, pero no rechaza ampliar su legitimidad echando mano de pasiones afines y de sucesos del pasado más o menos reciente (lo recién denominada propia psicología y memoria). En la mente de los soldados discurrían hechos como la burla inferida a la legión XIII durante la construcción del anfiteatro, el asesinato de mujeres llegadas a intervenir en la guerra y la reincidencia de la ciudad en su apoyo a Vitelio, todos ellos culpable de petulancia y de enemistad, que la codicia fácilmente transforma en propaganda para su causa. Pero donde ésta halla otras fuerzas de reserva con las que potenciar su propia naturaleza —insisto: ajena de suyo a cualquier motivación añadida— es en la cantera de su propia psicología, las pasiones del resentimiento y de la envidia, capaces de dar alas a la furia incluso en la vida privada pero que, instrumentalizadas al servicio del botín, no hay paz que las refrene. El mercado en curso potencia la opulencia inherente a la ciudad casi desde su fundación, es decir, multiplica la avidez al tentarla con cúmulos de objetos diversos con los que saciar temporalmente su estómago, el monstruo que reclama incesantes sacrificios una vez saturado de la sangre de las víctimas. La envidia hacia los opulentos será el expediente merced al cual la codicia recurra al botín para equilibrar la balanza alzando el platillo inferior hasta conseguir su peculiar forma de justicia. Pero será el resentimiento generado por el apoyo constante al enemigo, esa 
declaración permanente de hostilidad que los actos elevan a principio, el principal aliado de su naturaleza encontrado por la codicia al objeto de santificar el botín como justicia. El resentimiento ahoga en el fondo de su cieno la menor posibilidad de humanizar a la víctima, de empatizar con sus razones y entender sus intereses, de rebajar la pena preestablecida con los atenuantes de las circunstancias, de ser sensible a los sentimientos connaturales a todos los individuos. Llegados a ese punto sin retorno, la cuestión que aparentemente sale al paso es: ¿es la vida de los despojados separable de su hacienda o se mezclan necesariamente su dignidad y sus bienes? La narración de los hechos demuestra la ingenuidad de creer que el camino del botín podía concluir privando de sus bienes a sus expropietarios o incluso incluyendo vida y dignidad de los mismos en el lote usurpado. Nada hacía presagiar que el horror aguardaba paciente vigilando su curso para hacer irrupción en el atraco que la fuerza hace a la justicia cada vez que se autopremia el vencedor, ni que la humanidad podría desbordar de nuevo, como ya expusiera Tucídides al narrar la guerra de Corcira, los límites de la más brutal bestialidad.

\section{Codicia y horror: el placer del mal}

La orgía de violencia desatada en la ciudad, en manos ya de soldados, porteadores y vivanderos, aun tan extremada, no era nueva y poco tenía que envidiar, por ejemplo, a la recién mentada, pero los niveles de crueldad alcanzados, por inauditos, vuelven a parecer únicos al espectador, incapaz de familiarizarse con tanto horror como el perpetrado por individuos que en otros contextos habrían sido padres, hijos, esposos, amigos, vecinos o ciudadanos amables y honrados en mayor o menor grado. Pero la licencia para apropiarse del botín que cada uno logre obtener transitoriamente suprime la civilización y crea el estado de naturaleza sin más. Botín, esto es, cosas personalmente apropiables por quien se las lleve, significa directamente eso: disolución de la sociedad en la que tales cosas existen; disolución de la propiedad y de su derecho, que las han transformado en bienes; disolución de la condición de personas, a las que ya no se reconoce ni dignidad ni derechos, sino sólo la fuerza que les permita, a unos, retener lo que poseían, y a otros 
llevarse más cosas, o antes, que los otros, pero a las que se las podrán arrebatar durante un cierto tiempo después de obtenerlas; botín es igualmente disolución del ejército, de la autoridad, del título mismo de vencedor, de todas las instituciones, en suma, en ambas partes; o por compendiar: disolución del límite, de cuanto vincula a los individuos mediante reglas de índole diversa en civitates y construye conjuntos ordenados con ellas.

Cuando la marabunta entra en la ciudad - distinciones, rangos, títulos ya ilegítimos-, o mejor, en un escenario amorfo y accesible, la barahúnda está garantizada y las tropelías se suceden por doquier. El respeto sagrado que hasta hace unos instantes, para vencedores y vencidos, imponía la edad, la veneración que inspiraba o la dignidad que representaba, es profanado por la avidez, degradado a utensilio, confundido con los demás, y valorado en función del uso que se le pueda dar; quien pensara hallar cobijo bajo el manto de su venerable autoridad pronto advertirá que la ha perdido toda, y la persona que sea buena para ser violada, será usada así; y a la buena para ser asesinada, se la usará así, porque la persona que alcanzó la edad provecta ha dejado de encarnar protección, para sí o para otros, e incluso ella misma, apenas usable para otra cosa que para la befa y el escarnio, será objeto de burla hasta que el bufón descanse o mute actividad.

Esa forma amable de degradación, desde luego no se padecía cuando la víctima eran una doncella o un joven vigoroso, porque entonces cada componente de la turbamulta quería la pieza entera para sí, por lo que tirando con fuerza para apropiársela desgarraban sus miembros y su vida. Pero como la violencia no siempre paga a los traidores que se sirven de ella en sus propósitos, la sinfonía del horror que tenía reservada a sus devotos no hace sino estallar: aquéllos que deseaban apropiarse entera la pieza de la belleza o la juventud sufren la venganza inmediata de las víctimas despedazadas, pues acaban por "empujar a la mutua aniquilación a sus propios raptores". A partir de ahí, el hecho se convierte en derecho y el modelo es de continuo imitado, abocando a una bacanal de violencia que rebasa toda sordidez hasta exhumar los más profundos e inauditos bajos fondos de nuestra especie.

Dice Tácito: “[c]uando uno agarraba para sí el dinero o las ofrendas, ricas en oro, de los templos, terminaba degollado por la superior violencia de los otros”. El botín con 
el que la codicia pretende saciarse en cada raptor ha terminado por aislar a los soldados que entraron juntos a saquear a fin de sacralizar su derecho de vencedores, y ya son sólo lobos desconocidos y rivales, en el que el derecho de saqueo se autolimita en la fuerza del saqueador, esto es, lo limitan otros como él más fuertes que él. El lector avisado podrá exclamar aquí lo que ante los sucesos de Corcira: ¡la previsión de Hobbes, verificada! ${ }^{10}$ Y, como en Hobbes, "nada resultaba ilícito" de cuanto ahí tenía lugar. Sólo cambian el modo y el escenario de la conclusión, pero no la lógica del razonamiento, y Tácito adelanta el relativismo ético del pensador inglés apelando a la diversidad ontológica de los asaltantes en su estratigrafía y sus códigos, que componían en principio "un ejército de lenguas distintas, en el que había ciudadanos, aliados y extranjeros, diversas eran las ambiciones y cada cual tenía su concepto de lo justo”, en tanto en aquél las diferencias se daban entre los valores de los propios individuos naturales, particulares en cada uno y legítimos todos en ausencia de un concepto objetivo de bien y de una experiencia donde sustentarlo. Ahora bien, el botín desafía la imaginación a buscarlo en las regiones de lo invisible, donde algunos suponen que sus dueños lo ocultaron; siendo invisible, estando oculto, será más la cantidad del mismo y mayor su calidad; la codicia sabe que existe porque el codicioso habría hecho precisamente eso, y ya ha extrapolado su condición a la del vencido, y como la fuerza da derecho a todo sobre éste lo compele a exhumarlo sin reparar en medios, por tanto, también, "infligiéndoles heridas y torturas".

Todas las cosas a disposición de cada cual y todos los medios de obtenerlas. Pero ningún límite normativo, ningún obstáculo digno de reconocimiento a la acción de un sujeto en el que el estómago rige su mente y acumular sin continencia es la ley del estómago. El reino de la voluntad pura o reino de la fuerza pura, porque en una tal condición el derecho abstracto a todo se topa con el más brutal de los límites en realidad: la fuerza de realizarlo. Es lo que gráficamente Tácito representaba en esos individuos despedazados por sus compañeros de codicia mientras despedazaban a la víctima que hubieran querido íntegra para sí. La bacanal de la violencia, con todo, no ha llegado a su fin: para configurar en su plenitud el arte del horror aún falta su más preciada perla: el placer. El placer por el horror.

${ }^{10}$ La previsión, basada en la identidad de la naturaleza humana considerada, es por ello intemporal. 
Entre las últimas citas hemos saltado un párrafo que dice esto: "[l]levaban [quienes iban a la búsqueda de los tesoros ocultos] en sus manos teas encendidas que, concluido el saqueo, arrojaban por divertirse sobre las casas vacías y los templos despojados". Y es que, lo decíamos antes, "nada resultaba ilícito". Por ello se destruye por destruir, porque resulta placentero, como suele suceder en realidad con todo cuanto se haga en el reino de lo ilimitado, en tanto lo inaccesible guarda cierta imagen de familia con lo prohibido. Destruir es el acto apocalíptico por excelencia del codicioso, el rastro de placer que le inunda el alma de felicidad cuando ha conseguido hacer desaparecer tras de sí el mundo antiguo hoy destruido. Incendiar es la consumación final de la relación de la codicia con el placer, el ideal en el que una vez saciada quizá ella misma, gustosa, expiara su felicidad si por naturaleza no fuera insaciable. ${ }^{11}$ Goza entonces no dejando nada vivo fuera de sus manos, incendiando lo que no puede transportar consigo misma porque, no pudiendo eliminar las leyes de la física, el fuego le hace sentir con emoción su pasajera vecindad con la omnipotencia. La codicia quema las casas de los hombres como antes, reforzada o no por el odio, quemó los templos de los dioses, lo que -ironía del destino - les fuerza a huir en búsqueda de otros fieles que proteger; y esa tierra quemada que queda tras de sí es la sola huella viva de infamia y de placer que aún preserva los ecos de su paso.

\section{A modo de epílogo: el pueblo espectador o Roma como crisis}

Las tropas de Vespasiano ya habían llegado a Roma y en su mente el instinto es reproducir Cremona. Antonio querría calmarlas mínimamente demorando un día el ataque, por temor a que en pleno combate el fragor más estentóreo fuera el de la codicia y aquéllas, a sus órdenes, se desentendieran del pueblo, del Senado y de los dioses.

\footnotetext{
${ }^{11}$ Y lo que la hace insaciable la vuelve, por un lado, extensible a todos los bienes acumulables, mas la insta por otro a concentrarse en cuantas menos manos mejor siguiendo la propia ley inscrita en su naturaleza, idéntica en su lógica a la ley de la oligarquía o de la aristocracia, según Aristóteles, las llevaba naturalmente a concentrarse monárquicamente. Así se explica el que los codiciosos se despedazaran entre sí por los bienes codiciados con independencia de la titularidad de los mismos, que se practicaran entre sí, aun siendo compañeros, las mismas delicadezas que dedicaron a las víctimas.
} 
Empero, las tropas "miraban todo retraso con desconfianza", y fuerzan el ataque. En ese déjà-vu se verá, sin embargo, algo nuevo: la oprobiosa y partidista neutralidad del pueblo romano.

Con los dos ejércitos enfrentándose entre sí, la plebe espectadora jalea a sus favoritos, que ni siquiera son siempre los mismos, sino aquéllos a los que ve ganar, y pide a los luchadores que degüellen a los que desertan. Hay una razón y no es el castigo a quienes violan la aparente dignidad de combatir por la patria, sino otra más familiar: "el populacho [...] se quedaba con la mayor parte del botín”, esto es, de los bienes de los muertos, aprovechando la confusión de la escena. Quien creyera por lo expuesto hasta aquí que la codicia era una especie de heroína que prefería a los valientes y los premiaba con el botín por su victoria, y que, por ende, hacía ascos a la cobardía, al desapego o a la indolencia, no tiene más que seguir mirando el espectáculo, ya confundidos actores y espectadores. Lo que se ve es Roma; o mejor, lo que queda de aquella Roma que Virgilio quiso inmortalizar por siempre celeste. Y cómo se ve Roma, es así: "Toda la ciudad ofrecía una imagen cruel y horrible: de una parte combates y heridos, de otra parte baños y tabernas; también sangre y montones de cadáveres, y al lado las rameras y los que a ellas se asemejan". Por si aún no quedara claro continúa Tácito: "todas las pasiones de un ocio vicioso, todos los crímenes del más cruel de los cautiverios; hasta el punto de que se creería que la misma ciudad se entregaba a la rabia y a la orgía".

Como en el presente trabajo no nos hemos propuesto recorrer con la codicia todos los escenarios donde muestra su poder, sino ante todo mostrar su comportamiento donde éste es máximo, el del botín tras una batalla victoriosa de enjundia, renunciamos a intentar sopesar su contribución a la escena descrita, esa yuxtaposición obscena de sordidez y de lujo, de violencia e impasibilidad, de autoritarismo y alegría, aunque cabe intuir que su papel no sea precisamente indiferente en esa estampa que se sirve del negro para reflejar la situación política y social de la ciudad. El cuadro completo de la misma termina de perfilarse cuando el historiador recuerda que la ciudad ya conoció otros momentos en los que ejércitos en armas y la pasión de la crueldad llenaron también de violencia las calles y de sufrimiento las almas; pero esto último, señala con desesperada lucidez, es lo que ha cambiado en un sentido que hace ininteligible el cambio, 
inexplicables los hechos: ejércitos recorriendo las calles de Roma y crueldad torturando las vidas romanas, decíamos: "Pero ahora había una inhumana tranquilidad, y las diversiones no se interrumpieron ni por un momento: como si se tratara de una alegría más que se sumaba a los días de fiesta, [los miembros del populacho] se mostraban exultantes y gozaban sin importarles para nada los dos bandos, alegres con los públicos males". ${ }^{12}$

Roma es lo que aquí ha desaparecido con la crisis social y política que actualmente la define. El ideal - material y vivo durante tanto tiempo, pese a los muchos conflictos graves que la convulsionaron - de una ciudad autogobernada mediante una especie de forzada cooperación que el reconocimiento de los exempla de los antepasados por ambos bandos hacía más llevadera, de una ciudad cuya grandeza traería la paz al mundo conocido, como un día creyó Cicerón y otro creerá Aristides, arde también en las llamas del Capitolio. El imperio, aún por asentar, ya ha hecho que el nuevo sujeto político, el emperador, en gran medida títere del ejército, tenga otros títeres con los que juguetea, los mismos que antaño dieran lugar a la fórmula que definió la grandeza de Roma: Senatus populusque romanus, hoy meras sombras de lo que fueron, aunque al Senado aún quede al menos la vacía dignidad de su función ritual en el ejercicio del poder imperial. Un populus sin poder, en cambio, es sólo populacho, en cuyo corazón, del que por obligación legal ha desertado la ambición, aún ocupa un espacio privilegiado la codicia.

Pero como ésta ya no se esfuerza por ser cruel con una criatura que ha dejado de inspirar miedo, le permite el lujo de conformar un único cuerpo real, ese populacho que lejos de toda situación límite no necesita sembrar la muerte entre sus miembros mientras la sacian y que, ajeno a cuanto se decide en la esfera pública, puede añadir otro lujo al anterior: el de la indiferencia a cuanto de convulso o violento suceda en ella; el corazón plebeyo, falto de las pasiones que conmocionan la vida pública y falto de fuego en las que emocionan la vida privada, se ha vuelto más estéril y menos exigente, al punto que la codicia le asiste en su cobardía y hasta, en combinación con otras pasiones sobre las que no pretende ejercer un imperio perenne en un ser subordinado, le permite sobrevivirse

${ }^{12}$ Véase el entero par. 83 del libro III (la cursiva de una de las citas es nuestra). 
privadamente entre circenses oleadas de alegría. ¡Paradojas de un sujeto que, justo por su expulsión de la vida pública y su "inhumana" indolencia ante los males que la aquejan, es uno de los grandes actores de la crisis que sacude la república, a lo que responde, empero — sarcasmo en la paradoja_-, derivando de ella una fuente para su felicidad!

Para concluir. Difícil dar con una arcilla que moldee más la vida de los humanos. Siempre y por doquier omnipresente, a pesar del cerco de amenazas y castigos a que la someten normas y tradiciones, en momentos de éxtasis ${ }^{13}$ como el del reparto del generoso botín ofrecido por una rica urbe tras una guerra victoriosa ejecuta su venganza mostrando cuán cerca su poder ronda la omnipotencia. Avasalla el corazón del individuosoldado fijando un fin a su voluntad y organiza el sistema de las pasiones como medio para obtenerlo, en tanto roe desde sus cimientos el mundo de reglas y valores que la sociedad erige contra la tiranía de su capricho y el de sus adláteres ordinarios; en ese camino de destrucción la sangre de los vencidos llega a confundirse con la de algunos de los vencedores, a los que hace expiar con la muerte la devoción que sienten por ella. La codicia termina de componer su himno a la barbarie dejando un rastro de llamas y rastrojos que recrean en el tiempo su leyenda.

\footnotetext{
${ }^{13}$ Los únicos que traemos a colación aquí. Pero recuérdese, por añadir otro ejemplo, que en el pueblo espectador era la base de la indiferencia por el vencedor, como si quién - y cómo- venciese en nada afectara su futuro.
} 